\title{
ANALISIS PENGELOMPOKAN JUMLAH PENUMPANG BUS TRANS JOGJA MENGGUNAKAN METODE CLUSTERING K-MEANS DAN AGGLOMERATIVE HIERARCHICAL CLUSTERING (AHC)
}

\author{
Lisna Zahrotun \\ Program Studi Teknik Informatika Universitas Ahmad Dahlan \\ J1. Prof. Dr. Soepomo, Janturan, Yogyakarta 55164 \\ Telp: (0274) 563515 ext. 3208 \\ E-mail : lisna.zahrotun@tif.ac.id
}

\begin{abstract}
Abstrak
Teknik kluster merupakan teknik pengelompokan yang sudah di kenal, dimana dalam teknik ini bertujuan untuk mengelompokkan data ke dalam kluster sehingga setiap kluster berisi data yang semirip mungkin.Dengan memanfaatkan data dari dinas perhubungantentang jumlah penumpang Trans Jogja, maka dalam penelitian ini dilakukan pengelompokan jumlah penumpang berdasarkan jalur bus dan shelter dengan menggunakan metode clustering k-means, dan Agglomerative Hierarchical Clustering (AHC). Penelitian ini menghasilkan 3 cluster untuk metode K-Means dengan jumlah data untuk cluster 0 ada 15 data, cluster 1 ada 44 data dan cluster 2 ada 54 data. Dan metode AHC3 cluster dengan jumlah data untuk cluster 0 ada 2 data, cluster 1 ada 57 data dan cluster 2 ada 54 data. Sehingga dari hasil pengelompokkan tersebut dapat terlihat metode K-Means memiliki hasil yang lebih baik dari pada metode AHC
\end{abstract}

Kata kunci : shelter, clustering k-means, agglomerative hierarchical clustering .

\section{PENDAHULUAN}

Pertumbuhan penduduk di suatu negara akan berbanding lurus dengan kebutuhan sarana transportasi. Trans Jogja adalah sebuah sistem transportasi bus cepat, murah, dan berAC di seputar Kota Yogyakarta yang dicanangkan Dinas Perhubungan, Komunikasi, dan Informatika (Dishubkominfo) DIY. Berbeda dengan bus kota kebanyakan, bus Trans Jogja membutuhkan halte (shelter) khusus sebagai tempat pertemuan antara calon penumpang dengan bus.

Seiring perkembangan waktu, jumlah penumpang bus Patas Trans Jogja mengalami kenaikan dari waktu ke waktu. Namun, kenaikan tersebut belum ditopang dengan peningkatan jumlah shelter, sehingga banyak calon penumpang yang tidak terangkut di jalur bus Trans Jogja. Sedangkan disisi lain pada shelter-shelter tertentu hanya terdapat sedikit calon penumpang pada jam-jam tertentu. Selain itu banyak warga yang mengeluhkan sejumlah tempat yang masuk jalur, tetapi kurang ditemui adanya shelter. Sehingga banyak diantaranya yang ingin menggunakan jasa bus Trans Jogja, tetapi tidak terpenuhi karena tidak adanya shelter. (http \:transjogja.com)

Teknik kluster merupakan teknik pengelompokan yang sudah di kenal, dimana dalam teknik ini bertujuan untuk mengelompokkan data ke dalam kluster sehingga setiap kluster berisi data yang semirip mungkin. Menurut Santosa (2007) ada dua pendekatan dalam clustering, yaitu partisioning dan hirarki. 
Pada algoritma hierarchical clustering menurut Tang, dkk (2006 ) terdapat beberapa keunggulan yaitu tidak perlu menentukan jumlah klaster yang diinginkan karena proses dapat langsung dihentikan pada saat jumlah klaster sesuai dengan yang diinginkan. Namun algoritma ini juga memiliki kelemahan bergantung pada pemilihan teknik intercluster similarity yang lebih dikenal dengan istilah linkage. Beberapa kelemahan dari linkage tersebut adalah sensitif terhadap adanya outlier, kesulitan menangani variasi bentuk dan ukuran, dan memisahkan cluster yang besar.

Sedangkan Berkhin menyebutkan beberapa kelemahan algoritma K-means adalah: (1) sangat bergantung pada pemilihan nilai awal centroid, (2) tidak jelas berapa banyak cluster $\mathrm{k}$ yang terbaik, (3) hanya bekerja pada atribut numerik.

Algoritma K-means ini juga memiliki kelebihan yaitu dinilai cukup efisien, yang ditunjukkan dengan kompleksitasnya $\mathrm{O}(\mathrm{tkn})$, dengan catatan $\mathrm{n}$ adalah banyaknya obyek data, $\mathrm{k}$ adalah jumlah cluster yang dibentuk, dan $\mathrm{t}$ banyaknya iterasi. Biasanya, nilai $\mathrm{k}$ dan $\mathrm{t}$ jauh lebih kecil daripada nilai $\mathrm{n}$. Selain itu, dalam iterasinya, algoritma ini akan berhenti dalam kondisi optimum lokal (Tang, dkk 2005).

Dengan mengetahui kelebihan dan kelemahan Agglomerative Hierarchical Clustering (AHC) dan juga permasalahan pada Dinas Perhubungan tentang jumlah penumpan bus Trans Jogja maka dilakukan penelitian lanjutan dari penelitian sebelumnya yang telah dilakukan oleh penulis yaitu mengelompokkan jumlah penumpang bus dengan metode clustering $K$ Means ke dalam penelitian ini dengan judul "Analisis Pengelompokan Jumlah Penumpang Bus Trans Jogja Menggunakan Metode Clustering K-Means dan Agglomerative Hierarchical Clustering (AHC)".

\section{TINJAUAN PUSTAKA}

Irdiansyah (2007) dalam jurnalnya didapatkan informasi dari data penjualan yang besar yaitu sebagai gambaran untuk pengambilan keutusan bagi perusahaan. Pengelompokan dalam penelitian ini juga digunakan oleh perusahaan untuk membuat laporan mengenai karakteristik umum dari grup-grup konsumen yang berbeda. Clustering yang digunakan adalah Agglomerative Hierarchical Clustering Algorithm (AHC algorithm).

Pralita (2010) dalam penelitiannya ini penerapan JST digunakan untuk prediksi jumlah penumpang bus di Kabupaten Kebumen dengan menggunakan metode Backpropagation berdasarkan pada data bulan Januari 2004 sampai Juli 2009. Dari hasil pelatihan dan pengujian data yang telah dilakukan, dihasilkan nilai prediksi untuk Agustus 2009 adalah sebesar 21857 orang.

Zahrotun (2013) dalam penelitiannya melakukan pengelompokkan mengunakan metode clustering k-means. Dimana dalam penelitian ini masih perlu dikembangkan karena belum dapat menghasilkan data untuk setiap clusternya.

\section{DASAR TEORI}

Analisis kelompok (cluster analisis) adalah pekerjaan mengelompokkan data (objek) yang didasarkan hanya pada informasi yang ditemukan dalam data yang menggambarkan objek tersebut dan hubungan diantaranya (Tan, 2006 dalam buku Prasetyo, 2012). Ada beberapa cara yang dapat digunakan untuk mengukur jarak data ke pusat kelomok, di antaranya Euclidean (Bezdek, 1981 dalam buku Prasetyo, 2012) menggunakan formula sebagai berikut:

$$
D\left(x_{2}-x_{1}\right)=\left\|x_{2}-x_{1}\right\|_{2}=\sqrt{\sum_{j=1}^{p}\left|x_{2 j}-x_{1 j}\right|^{2}}
$$




\section{Algoritma Clustering K-Means}

K-Means merupakan algoritma clustering yang berulang-ulang. Algoritma K-Means dimulai dengan pemilihan secara acak $\mathrm{K}, \mathrm{K}$ disini merupakan banyaknya cluster yang ingin dibentuk. Kemudian tetapkan nilai-nilai $\mathrm{K}$ secara random, untuk sementara nilai tersebut menjadi pusat dari cluster atau biasa disebut dengan centroid, mean atau "means". Hitung jarak setiap data yang ada terhadap masing-masing centroid menggunakan rumus Euclidian hingga ditemukan jarak yang paling dekat dari setiap data dengan centroid. Klasifikasikan setiap data berdasarkan kedekatannya dengan centroid. Lakukan langkah tersebut hingga nilai centroid tidak berubah (stabil) (Pralita, 2010).

Pada tahapan iterasi, nilai centroid cluster ditentukan dengan cara menghitung rata-rata dari data yang terletak pada cluster yang sama menggunakan rumus berikut:

$$
v_{i j}=\frac{1}{N_{i}} \sum_{k=0}^{N_{i}} x_{k j}
$$

dimana:

i : indeks dari cluster

$\mathrm{j}$ : indeks dari variable

$\mathrm{k}$ : indeks dari data

$\mathrm{v}_{\mathrm{ij}}$ : nilai centroid cluster ke-i untuk variabel ke-j

$\mathrm{x}_{\mathrm{kj}}$ : nilai data ke-k yang ada di dalam cluster tersebut untuk variabel ke-j

$\mathrm{N}_{\mathrm{i}}$ : Jumlah data yang menjadi anggota cluster ke-i

\section{Algoritma Clustering AHC}

Pengelompokan hierarki aglomeratif merupakan metode pengelompokan hierarki dengan pendekatan bawah atas (bottom up). Proses pngelompokan dimulai dari masingmasing data sebagai satu buah kelompok, kemudian secara rekursif mencari kelompok terdekat sebagai pasangan untuk bergabung sebagai satu kelompok yang besar.Proses tersebut diulang terus sehingga tampak bergerak ke atas membentuk jenjang (hierarki). Cara ini membutuhkan parameter kedekatan kelompok (cluster proximity). (Prasetyo, 2012)

\section{Single Linked (Jarak Terdekat)}

Pada metode single linked (jarak terdekat), kedekatan di antara dua kelompok ditentukan dari jarak terdekat (terkecil) diantara pasangan diantara dua data dari dua kelompok yang berbeda (satu dakelompok dari kelompok pertama dan satu lagi dari kelompok yang lain, atau disebut juga kemiripan termaksimal. Formulasi tautan tunggalnya adalah (Prasetyo, 2012):

$$
\mathrm{D}_{\mathrm{UV}}=\min \left\{\mathrm{d}_{\mathrm{UV}}\right\}, \mathrm{d}_{\mathrm{UV}} \in \mathrm{D}
$$

\section{METODOLOGI}

\subsection{Subjek Penelitian}

Subjek penelitian yang akan dibahas adalah data mining untuk mengelompokkan jumlah penumpang Trans Jogja dalam satu hari

\subsection{Metode Pengumpulan Data}

\subsubsection{Studi Pustaka}

Merupakan pengumpulan data yang dilakukan dengan mencari, membaca dan mengumpulkan dokumen-dokumen sebagai referensi seperti buku, artikel dan literature-literatul yang berhubungan dengan data mining menggunakan metode clustering k-means,serta browsing di internet. 


\subsubsection{Observasi}

Metode observasi ini digunakan untuk mempelajari dan mengetahui secara langsung objek yang diteliti. Objek yang diteliti itu adalah jumlah penumpang Trans Jogja pada shelter musper untuk tiga jalur bus.

\section{HASIL DAN PEMBAHASAN}

\section{Penggunaan Agoritma K-Means}

Dari hasil pengolahan menggunakan metode K-Means dapat diperoleh hasil bahwa jumlah cluster 0 adalah 15 data, cluster 1 adalah 44 data, dan cluster 2 adalah 54 data. Dengan nilai titik pusat terdapat pada Gambar 4.2

\begin{tabular}{|c|c|c|c|c|}
\hline \multirow[b]{2}{*}{ Attribute } & \multicolumn{3}{|c|}{ Cluster\# } & \\
\hline & $\begin{array}{r}\text { Full Data } \\
\text { (113) }\end{array}$ & $\begin{array}{r}0 \\
\text { (15) }\end{array}$ & $\begin{array}{r}1 \\
(44)\end{array}$ & $\begin{array}{r}2 \\
(54)\end{array}$ \\
\hline & $======$ & $=$ & $======$ & $=======$ \\
\hline jamkedatangan & 3.4248 & 4 & 3.3636 & 3.3148 \\
\hline jalurbus & 19.115 & 24.2667 & 29.8864 & 8.9074 \\
\hline jumpenumpang & 12.3363 & 39.0667 & 10.1818 & 6.6667 \\
\hline
\end{tabular}

\section{Gambar 4.2 Titik Pusat Cluster K-Means}

Dan untuk data yang termasuk dalam cluster 0 ditampilkan dalam Tabel 4.3, cluster 1 ditampilkan dalam Tabel 4.4 dan cluster 2 ditampilkan dalam Tabel 4.5. Dalam cluster 0 ini merupakan data dimana jumlah penumpang dikategorikan banyak, cluster 1 jumlah penumpang sedang dan cluster 2 jumlah penumpang sedikit. Sebaran dari data terhadap ketiga cluster menghasilkan jumlah data pada masing-masing cluster sebagai berikut: cluster $0=15$ data, cluster $1=44$ data, dan cluster $2=54$ data. Dari hasil clustering terlihat bahwa densitas/kerapatan data pada masing-masing cluster terlihat seimbang, ini memperlihatkan bahwa data memiliki similiritas yang baik. 
Tabel 4.3 Data pada cluster 0 metode K-Means

\begin{tabular}{|l|l|l|l|l|}
\hline $\begin{array}{l}\text { Id } \\
\text { bus }\end{array}$ & jam & $\begin{array}{l}\text { Jalur } \\
\text { bus }\end{array}$ & Halte/ shelter & $\begin{array}{l}\text { jumlah } \\
\text { penumpang }\end{array}$ \\
\hline 49 & jp 15-17 & 3B & Terminal Concat & 74 \\
\hline 53 & jp 15-17 & 3B & Sarjito Barat & 21 \\
\hline 55 & jp 15-17 & 1B & Santika & 46 \\
\hline 63 & jp 15-17 & 1A & Malioboro 3 & 53 \\
\hline 65 & jp 15-17 & 2A & Malioboro 3 & 33 \\
\hline 69 & jp 15-17 & 1A & Janti 3 & 21 \\
\hline 71 & jp 15-17 & 2A & Termconcat & 37 \\
\hline 73 & jp 15-17 & 2B & Termconcat & 39 \\
\hline 77 & jp 15-17 & 2B & Papmi Selatan & 32 \\
\hline 79 & jp 15-17 & 3A & MT Haryono & 22 \\
\hline 81 & jp 15-17 & 2A & SD Pujokusuman & 55 \\
\hline 83 & jp 15-17 & 3A & SD Pujokusuman & 39 \\
\hline 75 & jp 15-17 & 3A & Papmi Selatan & 34 \\
\hline 97 & jp 15-17 & 2A & Kehutanan & 44 \\
\hline 99 & jp 15-17 & 3A & Kehutanan & 36 \\
\hline
\end{tabular}

Tabel 4.4 Data pada cluster metode 1 K-Means

\begin{tabular}{|c|c|c|c|c|}
\hline $\begin{array}{l}\text { Id } \\
\text { bus }\end{array}$ & Jam & $\begin{array}{l}\text { Jalur } \\
\text { bus }\end{array}$ & Halte/ shelter & $\begin{array}{l}\text { jumlah } \\
\text { penumpang }\end{array}$ \\
\hline 58 & jp 13-14 & $3 \mathrm{~B}$ & Papmi Utara & 11 \\
\hline 59 & jp $15-17$ & $3 \mathrm{~B}$ & Papmi Utara & 11 \\
\hline 60 & jp 13-14 & $3 \mathrm{~B}$ & Tejokusuman & 9 \\
\hline 61 & jp $15-17$ & $3 \mathrm{~B}$ & Tejokusuman & 13 \\
\hline 62 & jp 13-14 & $1 \mathrm{~A}$ & Malioboro 3 & 11 \\
\hline 64 & jp 13-14 & $2 \mathrm{~A}$ & Malioboro 3 & 6 \\
\hline 66 & jp 13-14 & $3 \mathrm{~A}$ & Malioboro 3 & 19 \\
\hline 67 & jp $15-17$ & $3 \mathrm{~A}$ & Malioboro 3 & 14 \\
\hline 68 & jp 13-14 & $1 \mathrm{~A}$ & Janti 2 & 19 \\
\hline 70 & jp 13-14 & $2 \mathrm{~A}$ & Termconcat & 13 \\
\hline 72 & jp 13-14 & $2 \mathrm{~B}$ & Termconcat & 16 \\
\hline 74 & jp 13-14 & $3 \mathrm{~A}$ & Papmi Selatan & 22 \\
\hline 75 & jp $15-17$ & $3 \mathrm{~A}$ & Papmi Selatan & 34 \\
\hline 76 & jp 13-14 & $2 \mathrm{~B}$ & Papmi Selatan & 8 \\
\hline 78 & jp 13-14 & $3 \mathrm{~A}$ & MT Haryono & 6 \\
\hline 80 & jp 13-14 & $2 \mathrm{~A}$ & SD Pujokusuman & 10 \\
\hline 82 & jp 13-14 & $3 \mathrm{~A}$ & SD Pujokusuman & 6 \\
\hline 86 & jp 13-14 & $3 \mathrm{~A}$ & Tegal turi Utara & 2 \\
\hline 88 & jp 13-14 & $3 \mathrm{~A}$ & wirosaban utara & 3 \\
\hline 89 & jp $15-17$ & $3 \mathrm{~A}$ & wirosaban utara & 12 \\
\hline 90 & jp 13-14 & $3 \mathrm{~A}$ & MBS Utara & 5 \\
\hline 91 & jp $15-17$ & $3 \mathrm{~A}$ & MBS Utara & 8 \\
\hline 92 & jp 13-14 & $1 \mathrm{~A}$ & JEC 1 & 12 \\
\hline
\end{tabular}

\begin{tabular}{|c|c|c|c|c|}
\hline $\begin{array}{l}\text { Id } \\
\text { bus }\end{array}$ & Jam & $\begin{array}{l}\text { Jalur } \\
\text { bus }\end{array}$ & Halte/ shelter & $\begin{array}{l}\text { jumlah } \\
\text { penumpang }\end{array}$ \\
\hline 92 & jp 13-14 & $1 \mathrm{~A}$ & JEC 1 & 12 \\
\hline 93 & jp 15-17 & $1 \mathrm{~A}$ & JEC 1 & 18 \\
\hline 94 & jp 13-14 & $3 \mathrm{~A}$ & JEC 1 & 11 \\
\hline 95 & jp 15-17 & $3 \mathrm{~A}$ & JEC 1 & 16 \\
\hline 96 & jp 13-14 & $2 \mathrm{~A}$ & Kehutanan & 26 \\
\hline 97 & jp 15-17 & $2 \mathrm{~A}$ & Kehutanan & 44 \\
\hline 98 & jp 13-14 & $3 \mathrm{~A}$ & Kehutanan & 27 \\
\hline 99 & jp $15-17$ & $3 \mathrm{~A}$ & Kehutanan & 36 \\
\hline 100 & jp 13-14 & $3 \mathrm{~A}$ & Janti Utara & 7 \\
\hline 101 & jp 15-17 & $3 \mathrm{~A}$ & Janti Utara & 24 \\
\hline 102 & jp 13-14 & $3 \mathrm{~A}$ & Disnaker & 4 \\
\hline 103 & jp 15-17 & $3 \mathrm{~A}$ & Disnaker & 11 \\
\hline 104 & jp 13-14 & $3 \mathrm{~A}$ & Instiper Selatan & 11 \\
\hline 105 & jp 15-17 & $3 \mathrm{~A}$ & Instiper Selatan & 16 \\
\hline 106 & jp 13-14 & $3 \mathrm{~A}$ & UPN & 3 \\
\hline 107 & jp 15-17 & $3 \mathrm{~A}$ & UPN & 7 \\
\hline 108 & jp 13-14 & $2 \mathrm{~A}$ & Manggung & 2 \\
\hline 109 & jp 15-17 & $2 \mathrm{~A}$ & Manggung & 6 \\
\hline 110 & jp 13-14 & $3 \mathrm{~A}$ & Manggung & 3 \\
\hline 111 & jp 15-17 & $3 \mathrm{~A}$ & Manggung & 11 \\
\hline 112 & jp 13-14 & $3 \mathrm{~A}$ & Sarjito Timur & 3 \\
\hline 113 & jp $15-17$ & $3 \mathrm{~A}$ & Sarjito Timur & 6 \\
\hline
\end{tabular}


Tabel 4.5 Data pada cluster 2 metode K-Means

\begin{tabular}{|l|l|l|l|l|}
\hline $\begin{array}{l}\text { Id } \\
\text { bus }\end{array}$ & Jam & $\begin{array}{l}\text { Jalur } \\
\text { bus }\end{array}$ & Halte/ shelter & $\begin{array}{l}\text { jumlah } \\
\text { penumpang }\end{array}$ \\
\hline 1 & jp 6-8 & 1B & Tamrin Senopati & 7 \\
\hline 2 & jp 13-14 & 1B & Tamrin Senopati & 0 \\
\hline 3 & jp 15-17 & 1B & Tamrin Senopati & 0 \\
\hline 4 & jp 17-19 & 1B & Tamrin Senopati & 0 \\
\hline 5 & jp 6-9 & 2B & Tamrin Senopati & 17 \\
\hline 6 & jp 13-14 & 2B & Musper & 15 \\
\hline 7 & jp 15-17 & 2B & Musper & 20 \\
\hline 8 & jp 13-14 & 3B & Musper & 8 \\
\hline 9 & jp 15-17 & 3B & Musper & 33 \\
\hline 10 & jp 13-14 & 3B & Lowanu barat & 1 \\
\hline 11 & jp 15-17 & 3B & Lowanu barat & 6 \\
\hline 12 & jp 13-14 & 3B & Wirosaban selatan & 5 \\
\hline 13 & jp 15-17 & 3B & Wirosaban selatan & 2 \\
\hline 14 & jp 13-14 & 3B & SMA 7 & 3 \\
\hline 15 & jp 15-17 & 3B & SMA 8 & 25 \\
\hline 16 & jp 13-14 & 3A & Ngabean & 8 \\
\hline 17 & jp 15-17 & 3A & Ngabean & 12 \\
\hline 18 & jp 13-14 & 3B & Ngabean & 6 \\
\hline 19 & jp 15-17 & 3B & Ngabean & 18 \\
\hline 20 & jp 13-14 & 2B & Ngabean & 1 \\
\hline 21 & jp 15-17 & 2B & Ngabean & 6 \\
\hline 22 & jp 13-14 & 1A & Jayakarta & 6 \\
\hline 23 & jp 15-17 & 1A & Jayakarta & 9 \\
\hline 24 & jp 13-14 & 1B & Jayakarta & 5 \\
\hline 25 & jp 15-17 & 1B & Jayakarta & 0 \\
\hline 26 & jp 13-14 & 3B & Jayakarta & 0 \\
\hline 27 & jp 15-17 & 3B & Jayakarta & 4 \\
\hline
\end{tabular}

\begin{tabular}{|l|l|l|l|l|}
\hline $\begin{array}{l}\text { Id } \\
\text { bus }\end{array}$ & Jam & $\begin{array}{l}\text { Jalur } \\
\text { bus }\end{array}$ & Halte/ shelter & $\begin{array}{l}\text { jumlah } \\
\text { penumpang }\end{array}$ \\
\hline 28 & jp 13-14 & 1B & HarjoLukito & 2 \\
\hline 29 & jp 15-17 & 1B & HarjoLukito & 9 \\
\hline 30 & jp 13-14 & 3B & HarjoLukito & 0 \\
\hline 31 & jp 15-17 & 3B & HarjoLukito & 3 \\
\hline 32 & jp 13-14 & 3B & Banguntapan & 9 \\
\hline 33 & jp 15-17 & 3B & Banguntapan & 11 \\
\hline 34 & jp 13-14 & 2B & Banguntapan & 6 \\
\hline 35 & jp 15-17 & 2B & Banguntapan & 12 \\
\hline 36 & jp 13-14 & 1B & JEC Concat & 0 \\
\hline 37 & jp 15-17 & 1B & JEC Concat & 3 \\
\hline 38 & jp 13-14 & 3B & JEC Concat & 1 \\
\hline 39 & jp 15-17 & 3B & JEC Concat & 3 \\
\hline 40 & jp 13-14 & 3B & MBS Selatan & 0 \\
\hline 41 & jp 15-17 & 3B & MBS Selatan & 2 \\
\hline 42 & jp 13-14 & 3B & Instiper & 5 \\
\hline 43 & jp 15-17 & 3B & Instiper & 9 \\
\hline 44 & jp 13-14 & 3B & Stikers & 3 \\
\hline 45 & jp 15-17 & 3B & Stikers & 7 \\
\hline 46 & jp 13-14 & 3B & JIH & 0 \\
\hline 47 & jp 15-17 & 3B & JIH & 0 \\
\hline 48 & jp 13-14 & 3B & Terminal Concat & 17 \\
\hline 50 & jp 13-14 & 2B & Kentungan & 3 \\
\hline 51 & jp 15-17 & 2B & Kentungan & 12 \\
\hline 52 & jp 13-14 & 3B & Sarjito Barat & 8 \\
\hline 54 & jp 13-14 & 1B & Santika & 6 \\
\hline 56 & jp 13-14 & 3B & Santika & 2 \\
\hline 57 & jp 15-17 & 3B & Santika & 10 \\
\hline & & & & \\
\hline
\end{tabular}

\section{Penggunaan Algoritma Clustering AHC}

Dari hasil pengolahan menggunakan metode AHC dapat diperoleh hasil bahwa jumlah cluster 0 adalah 32 data, cluster 1 adalah 57 data, dan cluster 2 adalah 54 data. Dan untuk data yang termasuk dalam cluster 0 ditampilkan dalam Tabel 4.6, cluster 1 ditampilkan dalam Tabel 4.7 dan cluster 2 ditampilkan dalam Tabel 4.8.

Sebaran dari data terhadap ketiga cluster menghasilkan jumlah data pada masing-masing cluster sebagai berikut: cluster $0=2$ data, cluster $1=57$ data, dan cluster $2=54$ data. Dari hasil clustering terlihat bahwa densitas/kerapatan data pada masing-masing cluster terlihat seimbang , ini memperlihatkan bahwa data memiliki similiritas yang kurang baik.

Tabel 4.6 Data pada cluster 0 metode AHC

\begin{tabular}{|l|l|l|l|l|}
\hline $\begin{array}{l}\text { Id } \\
\text { bus }\end{array}$ & Jam & Jalurbus & Halte/ shelter & $\begin{array}{l}\text { Jumlah } \\
\text { penumpang }\end{array}$ \\
\hline 1 & jp 6-8 & 1B & Tamrin Senopati & 7 \\
\hline 5 & jp 6-9 & 2B & Tamrin Senopati & 17 \\
\hline
\end{tabular}


Tabel 4.7 Data pada cluster 1 metode AHC

\begin{tabular}{|l|l|l|l|l|}
\hline $\begin{array}{l}\text { Id } \\
\text { bus }\end{array}$ & Jam & $\begin{array}{l}\text { Jalur } \\
\text { bus }\end{array}$ & Halte/ shelter & $\begin{array}{l}\text { Jumlah } \\
\text { penumpang }\end{array}$ \\
\hline 2 & jp 13-14 & 1B & Tamrin Senopati & 0 \\
\hline 3 & jp 15-17 & 1B & Tamrin Senopati & 0 \\
\hline 6 & jp 13-14 & 2B & Musper & 15 \\
\hline 7 & jp 15-17 & 2B & Musper & 20 \\
\hline 8 & jp 13-14 & 3B & Musper & 8 \\
\hline 10 & jp 13-14 & 3B & Lowanu barat & 1 \\
\hline 12 & jp 13-14 & 3B & Wirosaban sltan & 5 \\
\hline 14 & jp 13-14 & 3B & SMA 7 & 3 \\
\hline 16 & jp 13-14 & 3A & Ngabean & 8 \\
\hline 18 & jp 13-14 & 3B & Ngabean & 6 \\
\hline 20 & jp 13-14 & 2B & Ngabean & 1 \\
\hline 22 & jp 13-14 & 1A & Jayakarta & 6 \\
\hline 24 & jp 13-14 & 1B & Jayakarta & 5 \\
\hline 26 & jp 13-14 & 3B & Jayakarta & 0 \\
\hline 28 & jp 13-14 & 1B & HarjoLukito & 2 \\
\hline 30 & jp 13-14 & 3B & HarjoLukito & 0 \\
\hline 32 & jp 13-14 & 3B & Banguntapan & 9 \\
\hline 34 & jp 13-14 & 2B & Banguntapan & 6 \\
\hline 36 & jp 13-14 & 1B & JEC Concat & 0 \\
\hline 38 & jp 13-14 & 3B & JEC Concat & 1 \\
\hline 40 & jp 13-14 & 3B & MBS Selatan & 0 \\
\hline 42 & jp 13-14 & 3B & Instiper & 5 \\
\hline 44 & jp 13-14 & 3B & Stikers & 3 \\
\hline 46 & jp 13-14 & 3B & JIH & 0 \\
\hline 48 & jp 13-14 & 3B & Terminal Concat & 17 \\
\hline 50 & jp 13-14 & 2B & Kentungan & 3 \\
\hline 52 & jp 13-14 & 3B & Sarjito Barat & 8 \\
\hline 54 & jp 13-14 & 1B & Santika & 6 \\
\hline 56 & jp 13-14 & 3B & Santika & 2 \\
\hline & & & & \\
\hline
\end{tabular}

\begin{tabular}{|c|c|c|c|c|}
\hline $\begin{array}{l}\text { Id } \\
\text { bus }\end{array}$ & Jam & $\begin{array}{l}\text { Jalur } \\
\text { bus }\end{array}$ & Halte/ shelter & $\begin{array}{l}\text { Jumlah } \\
\text { penumpang }\end{array}$ \\
\hline 58 & jp 13-14 & $3 \mathrm{~B}$ & Papmi Utara & 11 \\
\hline 60 & jp 13-14 & $3 \mathrm{~B}$ & Tejokusuman & 9 \\
\hline 62 & jp 13-14 & $1 \mathrm{~A}$ & Malioboro 3 & 11 \\
\hline 64 & jp 13-14 & $2 \mathrm{~A}$ & Malioboro 3 & 6 \\
\hline 66 & jp 13-14 & $3 \mathrm{~A}$ & Malioboro 3 & 19 \\
\hline 68 & jp 13-14 & $1 \mathrm{~A}$ & Janti 2 & 19 \\
\hline 70 & jp 13-14 & $2 \mathrm{~A}$ & Termconcat & 13 \\
\hline 72 & jp 13-14 & $2 \mathrm{~B}$ & Termconcat & 16 \\
\hline 74 & jp 13-14 & $3 \mathrm{~A}$ & Papmi Selatan & 22 \\
\hline 76 & jp 13-14 & $2 \mathrm{~B}$ & Papmi Selatan & 8 \\
\hline 78 & jp 13-14 & $3 \mathrm{~A}$ & MT Haryono & 6 \\
\hline 80 & jp 13-14 & $2 \mathrm{~A}$ & SD Pujokusuman & 10 \\
\hline 82 & jp 13-14 & $3 \mathrm{~A}$ & SD Pujokusuman & 6 \\
\hline 84 & jp 13-14 & $3 \mathrm{~A}$ & Lowanu Timur & 0 \\
\hline 86 & jp 13-14 & $3 \mathrm{~A}$ & Tegal turi Utara & 2 \\
\hline 88 & jp 13-14 & $3 \mathrm{~A}$ & wirosaban utara & 3 \\
\hline 90 & jp 13-14 & $3 \mathrm{~A}$ & MBS Utara & 5 \\
\hline 92 & jp 13-14 & $1 \mathrm{~A}$ & JEC 1 & 12 \\
\hline 94 & jp 13-14 & $3 \mathrm{~A}$ & JEC 1 & 11 \\
\hline 96 & jp 13-14 & $2 \mathrm{~A}$ & Kehutanan & 26 \\
\hline 98 & jp 13-14 & $3 \mathrm{~A}$ & Kehutanan & 27 \\
\hline 100 & jp 13-14 & $3 \mathrm{~A}$ & Janti Utara & 7 \\
\hline 102 & jp 13-14 & $3 \mathrm{~A}$ & Disnaker & 4 \\
\hline 104 & jp 13-14 & $3 \mathrm{~A}$ & Instiper Selatan & 11 \\
\hline 106 & jp 13-14 & $3 \mathrm{~A}$ & UPN & 3 \\
\hline 108 & jp 13-14 & $2 \mathrm{~A}$ & Manggung & 2 \\
\hline 110 & jp 13-14 & $3 \mathrm{~A}$ & Manggung & 3 \\
\hline 112 & jp 13-14 & $3 \mathrm{~A}$ & Sarjito Timur & 3 \\
\hline
\end{tabular}

Tabel 4.8 Data pada cluster 1 metode AHC

\begin{tabular}{|c|c|c|c|c|c|c|c|c|c|}
\hline $\begin{array}{l}\text { Id } \\
\text { bus }\end{array}$ & jam & $\begin{array}{l}\text { Jalur } \\
\text { bus }\end{array}$ & Halte/ shelter & $\begin{array}{l}\text { jumlah } \\
\text { penumpang }\end{array}$ & $\begin{array}{l}\text { Id } \\
\text { bus }\end{array}$ & jam & $\begin{array}{l}\text { Jalur } \\
\text { bus }\end{array}$ & Halte/ shelter & $\begin{array}{l}\text { jumlah } \\
\text { penumpang }\end{array}$ \\
\hline 4 & jp 17-19 & 1B & Tamrin Senopati & 0 & 59 & jp 15-17 & $3 \mathrm{~B}$ & Papmi Utara & 11 \\
\hline 5 & jp 6-9 & $2 \mathrm{~B}$ & Tamrin Senopati & 17 & 61 & jp 15-17 & $3 \mathrm{~B}$ & Tejokusuman & 13 \\
\hline 9 & jp 15-17 & 3B & Musper & 33 & 63 & jp 15-17 & $1 \mathrm{~A}$ & Malioboro 3 & 53 \\
\hline 11 & jp 15-17 & $3 \mathrm{~B}$ & Lowanu barat & 6 & 65 & jp 15-17 & $2 \mathrm{~A}$ & Malioboro 3 & 33 \\
\hline 13 & jp 15-17 & 3B & Wirosaban selatan & 2 & 67 & jp 15-17 & $3 \mathrm{~A}$ & Malioboro 3 & 14 \\
\hline 15 & jp 15-17 & 3B & SMA 8 & 25 & 69 & jp 15-17 & $1 \mathrm{~A}$ & Janti 3 & 21 \\
\hline 17 & jp 15-17 & $3 \mathrm{~A}$ & Ngabean & 12 & 71 & jp 15-17 & $2 \mathrm{~A}$ & Termconcat & 37 \\
\hline 19 & jp 15-17 & $3 \mathrm{~B}$ & Ngabean & 18 & 73 & jp 15-17 & $2 \mathrm{~B}$ & Termconcat & 39 \\
\hline 21 & jp 15-17 & $2 \mathrm{~B}$ & Ngabean & 6 & 75 & jp 15-17 & $3 \mathrm{~A}$ & Papmi Selatan & 34 \\
\hline 23 & jp 15-17 & $1 \mathrm{~A}$ & Jayakarta & 9 & 77 & jp 15-17 & $2 \mathrm{~B}$ & Papmi Selatan & 32 \\
\hline 25 & jp 15-17 & $1 \mathrm{~B}$ & Jayakarta & 0 & 79 & jp 15-17 & $3 \mathrm{~A}$ & MT Haryono & 22 \\
\hline 27 & jp 15-17 & $3 \mathrm{~B}$ & Jayakarta & 4 & 81 & jp 15-17 & $2 \mathrm{~A}$ & SD Pujokusuman & 55 \\
\hline 29 & jp 15-17 & 1B & HarjoLukito & 9 & 83 & jp 15-17 & $3 \mathrm{~A}$ & SD Pujokusuman & 39 \\
\hline 31 & jp 15-17 & 3B & HarjoLukito & 3 & 85 & jp 15-17 & $3 \mathrm{~A}$ & Lowanu Timur & 0 \\
\hline 33 & jp 15-17 & $3 \mathrm{~B}$ & Banguntapan & 11 & 87 & jp 15-17 & $3 \mathrm{~A}$ & Tegal turi Utara & 0 \\
\hline 35 & jp 15-17 & $2 \mathrm{~B}$ & Banguntapan & 12 & 89 & jp 15-17 & $3 \mathrm{~A}$ & wirosaban utara & 12 \\
\hline
\end{tabular}




\begin{tabular}{|l|l|l|l|l|} 
37 & jp 15-17 & 1B & JEC Concat & 3 \\
\hline 39 & jp 15-17 & 3B & JEC Concat & 3 \\
\hline 41 & jp 15-17 & 3B & MBS Selatan & 2 \\
\hline 43 & jp 15-17 & 3B & Instiper & 9 \\
\hline 45 & jp 15-17 & 3B & Stikers & 7 \\
\hline 47 & jp 15-17 & 3B & JIH & 0 \\
\hline 49 & jp 15-17 & 3B & Terminal Concat & 74 \\
\hline 51 & jp 15-17 & 2B & Kentungan & 12 \\
\hline 53 & jp 15-17 & 3B & Sarjito Barat & 21 \\
\hline 55 & jp 15-17 & 1B & Santika & 46 \\
\hline 57 & jp 15-17 & 3B & Santika & 10 \\
\hline
\end{tabular}

\begin{tabular}{|l|l|l|l|l|}
91 & jp 15-17 & 3A & MBS Utara & 8 \\
\hline 93 & jp 15-17 & 1A & JEC 1 & 18 \\
\hline 95 & jp 15-17 & 3A & JEC 1 & 16 \\
\hline 97 & jp 15-17 & 2A & Kehutanan & 44 \\
\hline 99 & jp 15-17 & 3A & Kehutanan & 36 \\
\hline 101 & jp 15-17 & 3A & Janti Utara & 24 \\
\hline 103 & jp 15-17 & 3A & Disnaker & 11 \\
\hline 105 & jp 15-17 & 3A & Instiper Selatan & 16 \\
\hline 107 & jp 15-17 & 3A & UPN & 7 \\
\hline 109 & jp 15-17 & 2A & Manggung & 6 \\
\hline 111 & jp 15-17 & 3A & Manggung & 11 \\
\hline 113 & jp 15-17 & 3A & Sarjito Timur & 6 \\
\hline
\end{tabular}

Dari hasil pengelompokkan menggunakan metode clustering K-Means dan clustering AHC maka dalam penelitian ini terlihat hasil dari pengelompokkan clustering $K$-Means memiliki kemiripan yang lebih seimbang untuk setiap kelompokknya dibandingkan dengan hasil dari pengelompokkan clustering AHC. Sehingga dapat disimpulkan meskipun pada proses clustering KMeans harus menentukan centroid atau titik terlebih dahulu namun dalam kasus ini dapat menghasilkan data pengelompokkan yang labih baik. Sedangkan untuk hasil pengelompokkan menggunakan metode AHC meskipun lebih efisien karena tidak menggunakan titik pusat pada awal pengelompokkan dan hanya menghitung tingkat kemiripan memiliki hasil yang kurang baik.

\section{KESIMPULAN DAN SARAN}

Setelah melakukan data mining dengan algoritma clustering K-Means dan clustering AHC pada jumlah penumpang bus Trans Jogja, maka dapat ditarik kesimpulan sebagai berikut :

1. Hasil dari data mining yang dapat digunakan untuk menampilkan informasi pengelompokkan jumlah penumpang berdasarkan jam, halte/shelter dan jalur bus.

2. Hasil dari proses clustering $K$-Means ini didapatkan 3 cluster dengan jumlah data untuk cluster 0 ada 15 data, cluster 1 ada 44 data dan cluster 2 ada 54 data.

3. Hasil dari proses clustering K-Means ini didapatkan 3 cluster dengan jumlah data untuk cluster 0 ada 2 data, cluster 1 ada 57 data dan cluster 2 ada 54 data.

4. Dalaam penelitian ini dihasilkan metode K-Means memiliki hasil yang lebih baik dari pada metode AHC. 
Aplikasi data miningyang dihasilkan pada penelitian ini masih perlu dikembangkan lebih lanjut dalam hal data yang ditampilkan tidak hanya berupa data namun juga dapat digambarkan dalam bentuk grafik dan dendograf yang lebih jelas.

\section{DAFTAR PUSTAKA}

Berkhin, Pavel. Survey on clustering data mining techniques, http://www.ee.ucr.edu/ barth/EE242/clustering survey.pdf di akses pada Desember 2013

Irdiansyah 2007, "Penerapan Data Mining Pada Penjualan Minuman di PT.Pepsi Cola Indobeverages Menggunakan Metode Clustering"

Pralita, F. 2010 ,"Penerapan Jaringan Syaraf tiruan Untuk Memprediksi Jumlah Penumpang Bus Dengan Metode BackPropagation", Skripsi, Fakultas MIPA, Universitas Islam Indonesia.

Prasetyo, Eko. 2012, "Data Mining Konsep dan Aplikasi Menggunakan Matlbab", Andi offset, Yogyakarta.

Santosa, Budi, 2007, “Data Mining Teknik Pemanfaatan Data untuk Keperluan Bisnis”, Graha Ilmu, Yogyakarta.

Tan, Pang-Ning,; Steinbach,Michael; Kumar ,Vipin, 2006 Data Mining Cluster Analysis : Basic Concepts and Algorithms. http://www-users.cs.umn.edu/ kumar/dmbook/index.php di akses pada Desember 2013

Tang, ZhaoHui; MacLennan, Jamie. 2005. Data Mining with SQL Server 2005. Indiana Polis : Wiley Publishing

Zahrotun, L, Perancangan Data Mining Pengelompokan Jumlah Penumpang Trans Jogja menggunakan metode clustering K-Means, Seminar Teknik Informatika, Universitas Ahmad Dahlan. 2013, Yogyakarta. 134-142

http://transjogja.com/gunakan-trans-jogja/, tanggal akses 12 Desember 2013 